\title{
ANALISIS PELAYANAN PURNA JUAL PRODUK PONSEL EVERCOSS TERHADAP LOYALITAS KONSUMEN
}

Oleh : Hendri Suparto

Strategi pemasaran dengan memberikan pelayanan purna jual non materi merupakan salah satu persaingan unsur non materi. Penelitian ini dilakukan untuk menguji pengaruh layanan purna jual terhadap loyalitas konsumen.

Sampel yang digunakan dalam penelitian ini berjumlah 80 responden. Adapun metode pengambilan sampel dengan menggunakan quota sampling.

Metode analisis data yang digunakan adalah analisis kuantitatif dengan menggunakan analisis regresi berganda. Kesimpulan dari penelitian ini adalah variabel garansi berpengaruh signifikan terhadap loyalitas konsumen dengan nilai $t$ hitung sebesar 3,049. Sedangkan aksesoris tidak berpengaruh signifikan terhadap loyalitas konsumen dengan nilai t hitung sebesar 1,923.

Sedangkan perlengkapan berpengaruh signifikan terhadap loyalitas konsumen dengan nilai t hitung sebesar 2,317. Secara simultan garansi, aksesoris, dan perlengkapan berpengaruh signifikan terhadap loyalitas konsumen dengan F hitung sebesar 13,275.

Kata Kunci: Loyalitas Konsumen, Garansi, Aksesoris, Perlengkapan 


\section{PENDAHULUAN}

Persaingan penjualan produk yang berjalan saat ini tidak sematamata bertumpu pada persaingan yang berhubungan dengan unsur materi atau fisik produk, antara lain: harga, kualitas, pelayanan, merek. Strategi pemasaran dengan memberikan pelayanan purna jual non materi merupakan salah satu persaingan unsur non materi. Pada dasarnya tujuan dari strategi tersebut adalah untuk mendongkrak penjualan baik untuk pangsa pasar yang berjalan (lama) dan untuk mendapatkan pangsa pasar baru.

Pelayanan purna jual yang dilakukan saat ini tidak hanya pada barang konsumsi yang bersifat fisik, bahkan yang bersifat jasa juga menerapkan hal yang sama. Sehingga unsur pelayanan purna jual bagaikan lagu wajib bagi produsen atau penjual untuk mempertahankan konsumen dan untuk menggaet konsumen baru.

Secara spesifik, harapan dari strategi tersebut adalah membangun fanatisme terhadap merek produk disadari atau tanpa disadari oleh konsumen. Nilai yang terkandung pada pelayanan purna jual memang sulit dinilai secara materi, sifatnya cendrung menjurus pada kepuasan psikologis (emosional). Konsumen yang menerima pelayanan purna jual akan memberi kesan dan apresiasi besar tanpa menilai secara materi..

Ponsel evercoss di pelopori oleh PT. Aries Indo Global selaku perusahaan pemegang merek. Evercoss adalah merek ponsel lokal yang di produksi oleh negara China dan dipasarkan di Indonesia. Hingga pada tahun 2013 evercoss terjual dengan jumlah 1,5 juta unit perbulan diseluruh outlet di Indonesia, sehingga pada akhir tahun 2013 perusahaan membangun pabriknya di Indonesia, itu menandakan ponsel evercoss adalah satu-satunya merek lokal yang di produksi di Indonesia. (sumber: SWA.co.id)

Sekarang ini, produsen yang memproduksi produk elektonik, menjual produk tersebut dengan garansi. Garansi (warranty) adalah 
suatu perjanjian krontraktual yang mengharuskan produsen untuk merektifikasi (memperbaiki atau mengganti) produk yang mengalami kerusakan selama masa garansi. Umumnya perbaikan produk rusak tidak dikenakan biaya kepada konsumen. Untuk garansi tertentu, rektifikasi mengharuskan pengembalian uang (money back) sebagian atau $100 \%$ dari harga jual kepada konsumen.

Sangat sulit untuk mengetahui kapan tepatnya garansi pertama kali dikenalkan. Namun, jika garansi dipandang sebagai liabilitas produk (pertanggung-jawaban produsen) sejak saat itu, hak konsumen untuk mendapatkan produk yang baik dalam transaksi pembelian produk dilindungi. Di Indonesia, undangundang yang melindungi hak konsumen terdapat pada UndangUndang nomor 8 tahun 1999 tentang Perlindungan Konsumen. Dengan undang-undang ini, produsen/pelaku usaha yang memproduksi produk/barang yang umur pakainya 1 (satu) tahun atau lebih, wajib menyediakan suku cadang dan fasilitas purna jual serta memberikan garansi.

Menawarkan produk dengan garansi berarti tambahan ongkos bagi produsen, karena harus memperbaiki produk rusak (atau disebut layanan garansi) selama masa garansi. Ongkos garansi ini membebani produsen secara signifikan dengan sebaran ongkos $1,5-3 \%$ dari total penjualan (Blischke dkk, 1994). Dengan demikian gagal dalam mengelola garansi secara efektif berakibat bukan saja ongkos pelayanan garansi yang tidak terkendali tapi juga berdampak pada ketidakpuasan konsumen dan kehilangan penjualan. Ini selanjutnya berdampak negatif terhadap kinerja perusahaan secara keseluruhan.

Layanan purna jual ini diterapkan akan membangun hubungan jangka panjang yang signifikan dengan pelanggan sehingga pelanggan menerima lebih banyak nilai dari jasa yang ditawarkan, membantu karyawan bengkel menjadi lebih kompetitif dengan meningkatkan kinerja mereka dan dapat menciptakan pengertian yang mendalam mengenai pelanggan 
sehingga bisa menyediakan pandangan dari dalam yang berguna mengenai masalah pelanggan.

Jember adalah pasar yang sangat berpotensi bagi produsen ponsel, dengan jumlah penduduk 2.332.726 jiwa sesuai sensus penduduk 2010 dengan pendapatan rata-rata Rp. 36,5 juta perkapita yang disinyalir sangat mudah dipengaruhi dan gemar berbelanja. (sumber : BPS Kab. Jember)

Dalam penelitian ini peneliti memfokuskan produk menjadi obyek yang diteliti, terbukti dari variabel independen indikator dari masingmasing variabel adalah teori dari produk. Sedangkan lokasi penelitian hanya sebagai tempat studi kasus. Rumusan masalah dari penelitian ini adalah "Apakah pelayanan purna jual produk ponsel evercoss berpengaruh terhadap loyalitas konsumen di JTeknik cellular Jember baik secara simultan maupun secara parsial?"

Adapun tujan dari penelitian ini adalah : (a) Ingin mengetahui apakah pelayanan purna jual berpengaruh terhadap loyalitas konsumen di outlet J-Teknik cellular, (b) Ingin mengetahui apakah garansi berpengaruh terhadap loyalitas konsumen di outlet J-Teknik cellular, (c) Ingin mengetahui apakah penyediaan aksesoris berpengaruh terhadap loyalitas konsumen di outlet J-Teknik cellular, dan (d) Ingin mengetahui apakah penyediaan perlengkapan berpengaruh terhadap loyalitas konsumen di outlet JTeknik cellular. 


\section{TINJAUAN PUSTAKA}

\section{Pemasaran}

Menurut Kotler (1997:8) pemasaran adalah suatu proses sosial dan manajerial yang didalamnya individu dan kelompok mendapatkan apa yang mereka butuhkan dan inginkan dengan menciptakan, menawarkan dan mempertukarkan produk yang bernialai dengan pihak lain. Sedangkan definisi menurut Stanton (1994:7) pemasaran adalah suatu sistem total dari kegiatan bisnis yang dirancang untuk merencanakan, menentukan harga, mempromosikan dan mendistribusikan barang-barang yang memuaskan keinginan dan jasa baik kepada para konsumen saat ini maupun konsumen potensial.

Manajemen pemasaran merupakan kegiatan yang dikoordinasikan dan dikelola dengan baik. Definisi manajemen pemasaran Swastha (1997:4) manajemen pemasaran adalah penganalisaan, perencanaan, dan pengawasan program-program yang bertujuan menimbulkan pertukaran dengan pasar yang dituju dengan maksud untuk mencapai tujuan perusahaan. Menurut Kotler

(1997:18) manajemen pemasaran adalah proses perencaan dan pelaksanaan pemikiran, penetapan harga, promosi, serta penyaluran gagasan, barang dan jasa untuk menciptakana pertukaran yang memuaskan tujuantujuan individu dan organisasi.

\section{Layanan Purna Jual}

Pemberian pelayanan purna jual kepada pelanggan biasannya diberikan sebagai suatu tanggung jawab penjual atas kualitas barang yang dijualnya. Pelayanan ini diberikan dalam bentuk pemberian garansi, penggantian barang-barang rusak, pemeliharaan dan penyedian suku cadang (Barata, 2003:290). Sedangkan Kotler (2002: 508) mengatakan "Layanan purna jual adalah layanan yang diberikan perusahaan kepada seorang konsumen setelah terjadinya transaksi penjualan". Sedangkan menurut Tjiptono (2008:136) Layanan purna jual adalah suatu 
layanan yang disediakan oleh produsen kepada konsumen setelah konsumen tersebut membeli produk dari perusahaan tersebut. Berdasarkan pengertian di atas dapat disimpulkan bahwa layanan purna jual adalah suatu kegiatan yang dilaksanakan setelah penyerahan produk kepada konsumen atas pembeliannya, yang berlaku selama konsumen ada ikatan layanan atau hubungan dalam berbagai kegiatan layanan.

Didalam tanggung jawab produk bukan hanya membatasi pada produk cacat saja. Tanggung jawab produk adalah bagian dari transaksi konsumen, sedangkan layanan purna jual meliputi permasalahan yang luas dan mencakup masalah kepastian atas:

1. Ganti rugi jika barang atau jasa yang diberikan tidak sesuai dengan perjanjian semula.

2. Barang yang digunakan, jika mengalami kerusakan tertentu, dapat diperbaiki secara cumacuma selama jangka waktu garansi.

3. Suku cadang selalu tersedia dalam jangka waktu yang relatif lama setelah transaksi konsumen dilakukan.

\section{Unsur-unsur Layanan Purna} Jual

Layanan purna jual memiliki beberapa unsur, sebagaimana unsurunsur dalam layanan purna jual adalah sebagai berikut:

a. Garansi

Garansi merupakan salah satu faktor yang sangat penting dalam melaksanakan layanan purna jual, seperti dikatakan oleh Kotler (2002: 508) bahwa:

A warranty assures the buyer that a product is of kind specified (Meet Specification) and is free of encumbrances (Defect Workmanship or Material) A guarantee assures that a product performance will amply with the warranty. Simply stated if the product does not melt the term of the listed warranty, it will be repaired or replaced at the option of seller.

Garansi ditunjukan untuk meyakinkan konsumen bahwa produk dalam keadaan baik atau bebas dari kerusakan, akibat dari ketidaktelitian pengarjaan atau penggunaan material yang kurang 
baik yang berlaku untuk jangka waktu tertentu.

\section{b. Penyediaan Accesories}

Dalam pelaksanaan layanan purna jual, penyediaan suku cadang merupakan hal yang sangat penting, sebab tanpa adanya suku cadang produk yang sudah rusak komponennya tidak dapat berfungsi dengan baik, bahkan produk tersebut tidak dapat dipakai lagi. Kotler (2002: 509) mengatakan:

A service parts is that component or subassembly that may be needed at some time to keep the appliance or device operable for the user. The component or assembly will be required to satisfy the original warranty repair the appliance or device beyond the basic warranty period, and be available at all the times to insure and protect the good will of purchases to the and that be will maintains his brand loyalty.

Jadi penyediaan accessories merupakan salah satu faktor yang memegang peranan penting dalam usaha untuk memuaskan konsumen, yang pada akhirnya akan mempertahankan loyalitas pelanggan yang sudah dimiliki.

c. Pelayanan Pemeliharaan dan Perbaikan
Pelayanan dan pemeliharaan dan perbaikan diperlukan apabila suatu produk memiliki masa konsumsi yang lama dan memerlukan perawatan yang teratur agar dapat selalu berfungsi dengan baik, dan juga untuk melakukan perbaikan atas kerusakan yang terjadi pada produk tersebut selama pemakaiannya.

d. Fasilitas dan Perlengkapan

Fasilitas dan perlengkapan suatu produk merupakan sarana untuk melakukan layanan purna jual. Peralatan dan perlengkapan yang canggih akan dapat menentukan kelancaran pelayanan petugas dalam melakukan pemeliharaan dan perbaikan produk yang dibeli konsumen.

\section{Perilaku konsumen}

Seiring dengan meningkatnya pertumbuhan ekonomi di Indonesia saat ini, maka masyarakat semakin pandai menyeleksi barang dan jasa yang akan dikonsumsi. Oleh karena itu agar perusahaan dapat mengembangkan usahanya maka ia harus mengetahui perilaku konsumen sehingga kehadiran pelanggan dapat terjaga. Sikap dan perilaku 
konsumen akan mempunyai pengaruh yang cukup besar dalam menentukan suatu strategi bagi suatu perusahaan. Menurut Winardi (1991:14), perilaku konsumen dapat dirumuskan sebagai perilaku yang ditujukan oleh orang-orang dalam hal merencanakan, membeli dan menggunakan barang-barang ekonomi dan jasa. Sedangkan menurut Engel dkk, (1994:3), Perilaku konsumen adalah sebagai tindakan yang langsung terlibat dalam mendapatkan, mengkonsumsi, dan menghabiskan produk dan jasa, termasuk proses yang mendahului dan menyusuli tindakan ini.

\section{Loyalitas konsumen}

Loyalitas konsumen secara umum dapat diartikan kesetiaan seseorang atas sesuatu produk, baik barang maupun jasa tertentu. Loyalitas konsumen merupakan manifestasi dan kelanjutan dari kepuasan konsumen dalam menggunkan fasilitas maupun jasa pelayanan yang diberikan oleh pihak perusahaan, serta untuk tetap menjadi konsumen dari perusahaan tersebut. Loyalitas adalah bukti konsumen yang selalu menjadi konsumen, yang memiliki kekuatan dan sikap positif atas perusahaan itu.

Kesetiaan konsumen terhadap suatu barang atau jasa merek tertentu tergantung pada beberapa faktor, besarnya biaya untuk berpindah ke merek barang atau jasa yang lain, adanya kesamaan mutu, kualitas atau pelayanan dari jenis barang atau jasa pengganti, adanya resiko perubahan biaya akibat barang atau jasa pengganti dan berubahnya tingkat kepuasan yang didapat dari merek baru dibanding dengan pengalaman terhadap merek sebelumnya yang pernah dipakai. Konsumen dalam memenuhi kebutuhan dan keinginannya, akan membeli produk dengan merek tertentu. Apabila merek yang dipilih konsumen itu dapat memuaskan kebutuhan dan keiginannya, maka konsumen akan memiliki suatu ingatan yang dalam terhadap merek tersebut.

Kesetiaan pelanggan adalah aset yang bernilai strategik, maka peneliti perilaku konsumen tertarik untuk mengembangkan dan memformulasikan konsep beserta pengukurannya. Masalah pokok yang 
timbul bagi para peneliti adalah bagaimana mendefinisikan istilah kesetiaan, apakah istilah tersebut dikaitkan dengan perilaku konsumen ataukah sikap konsumen. Pada awal perkembangannya kesetiaan pelanggan lebih dikaitkan dengan perilaku. Ini dapat dilihat dari teori belajar tradisional (Classical dan Instrumental Conditioning) yang cenderung melihat kesetiaan dari aspek perilaku. Konsumen dianggap mempunyai kesetiaan terhadap suatu merek tertentu jika ia telah membeli merek yang sama tersebut sebanyak tiga kali berturut-turut. Kendalanya adalah kesulitan dalam membedakan antara yang benar-benar setia dengan yang palsu meskipun perilakunya sama.

Menurut beberapa pakar loyalitas atau kesetiaan konsumen dapat diartikan sebagai suatu sikap konsumen terhadap penyedia jasa, sementara yang lainnya mendefinisikan loyalitas dari sudut pandang dari penyedia jasa yaitu sikap penyedia jasa terhadap konsumennya. Perbedaan definisi ini disebabkan karena tidak adanya kesatuan definisi yang diberikan pada istilah loyalitas. Ada beberapa definisi kesetiaan yang dikemukakan oleh para ahli:

a. Hurriyati (2008:129) memberikan definisi tentang Loyalitas Konsumen sebagai berikut :

Loyalty is defined as non random purchase expressed over time by some decision making unit

Berdasarkan definisi tersebut dapat dijelaskan bahwa loyalitas lebih mengacu pada wujud perilaku dari unit-unit pengambilan keputusan untuk melakukan pembelian secara terus menerus terhadap barang atau jasa suatu perusahaan yang dipilih.

b. Terciptanya kepuasan dapat memberikan beberapa manfaat, diantaranya hubungan antara perusahaan dengan pelanggannya menjadi harmonis sehingga memberikan dasar yang baik bagi pembelian ulang dan terciptanya kesetiaan terhadap merek serta membuat suatu rekomendasi dari mulut ke mulut (word of mouth) yang menguntungkan bagi perusahaan (Tjiptono, 2000:105).

c. Menurut Hasan (2008:83) Loyalitas pelanggan dedefinisikan 
sebagai orang yang membeli, khusunya yang membeli secara teratur dan berulang-ulang. Pelanggan merupakan seseorang yang terus menerus dan berulang kali datang ke suatu tempat yang sama untuk memuaskan keinginannya dengan memiliki suatu produk atau mendapatkan suatu jasa dan membayar produk atau jasa tersebut".

d. Menurut Tjiptono (2000:110) Loyalitas Konsumen adalah komitmen pelanggan terhadap suatu merek, toko atau pemasok berdasarkan sifat yang sangat positif dalam pembelian jangka panjang. Dari pengertian ini dapat diartikan bahwa kesetiaan terhadap merek diperoleh karena adanya kombinasi dari kepuasan dan keluhan.

e. Menurut Griffin (1995:19) pembentukan Loyalitas akan melalui siklus pembelian yang terdiri dari 5 tahap, yaitu:

- Kesadaran (Awareness).

Tahap pertama menuju terbentuknya loyalitas, ditandai dan tumbuhnya kesadaran konsumen terhadap suatu produk/jasa. Konsumen menyadari keberadaan suatu penyedia produk/jasa dari iklan, pengirim surat langsung oleh penyedia produk jasa, komunikasi dari mulut ke mulut, dari kegiatan pemasaran seperti pameran. Pada tahap ini ikatan yang terjadi antara konsumen dengan penyedia produk/jasa sangat kecil.

- Pembelian pertama (initial purchase)

Pembelian pertama merupakan tahap yang paling genting dalam pembentukan loyalitas pelanggan. Pembelian pertama sama dengan pembelian penting dan kesempatan ini penyedia produk/jasa dapat membangun kesan positif atau negatif dalam benak pelanggan melalui produk, kualitas pelayanan, dan lingkungan fisiko

- Evaluasi purnabeli (post purchase)

Setelah pembelian terjadi konsumen secara sadar mengevaluasi transaksi yang telah dialaminya, yang akhirnya akan menunjukkan kepuasan atau ketidakpuasan. Faktor kepuasan atau ketidakpuasan akan memungkinkan konsumen beralih kepada produkljasa pesaing atau justru akan 
mengambil kepada keputusan pembelian ulang

- Keputusan pembelian ulang (decision to repurchase)

Komitmen atau kepercayaan untuk pembelian ulang adalah sikap yang sangat penting bagi pembentukan loyalitas pelanggan, bahkan lebih mendasar daripada kepuasan. Motivasi untuk pembelian ulang berasal dari sikap positif terhadap suatu produk/jasa pesaing. Pada tahap ini telah terjadi ikatan emosional yang kuat terhadap produkljasa. Ikatan emosional yang dirasakan konsumen akan menuntut konsumen pada keputusan pembelian ulang.

- Pembelian

ulang (Repurchase)

Tahap yang terakhir ini, siklus pembelian adalah terjadinya prilaku pembelian ulang yang sesungguhnya/nyata. Agar diakui sebagai pelanggan loyal sejati, konsumen harus melakukan pembelian berulang secara konsisten dari penyedia produk/jasa yang sarna.
Griffin mengungkapkan bahwa indikator-indikator loyalitas pelanggan adalah sebagai berikut:

- Rata-rata pembelian ulang, yaitu kemungkinan akan membeli lagi bila membutuhkan prod uk atau jasa yang sama. Pelanggan yang memiliki ratarata pembelian yang lebih tinggi berarti dapat dikatakan lebih loyal daripada pelanggan dengan rata-rata pembelian yang lebih rendah.

- Membeli produk dan pelayanan yang sarna, yaitu pelanggan akan membeli produk dan pelayanan pada perusahaan yang sama. Ukuran loyalitas pelanggan berkembang pada perilaku pembelian terhadap produk baru yang dikeluarkan perusahaan.

- Memberikan rekomendasi atau mempromosikan produk kepada orang lain, yaitu pelanggan yang loyal akan merekomendasikan dan menceritakan pengalaman positif mengenai produk dan jasa dari badan usaha tersebut pada pelanggan lain.

- Menunjukkan kekebalannya (akan produk yang dimaksud) dalam persaingan, yaitu pelanggan yang loyal tidak goyah untuk beralih pada produsen lain karena pelanggan 
tersebut yakin bahwa produk dan jasa dari badan usaha yang mereka pilih adalah yang terbaik dan berbeda dari produk dan jasa badan usaha lain.

6. Unsur-unsur

Loyalitas konsumen

Unsur - unsur loyalitas meliputi : (1) Melakukan pembelian berulang secara teratur, (2) Membeli antarlini produk dan jasa, (3) Mereferensikan kepada orang lain, dan Menunjukkan kekebalan terhadap tarikan dari pesaing. Dalam mengukur kesetiaan, diperlukan beberapa atribut yaitu: (a) Mengatakan hal yang positif tentang perusahaan kepada orang lain, (b) Merekomendasikan perusahaan kepada orang lain yang meminta saran, (c) Mempertimbangkan bahwa perusahaan merupakan pilihan pertama dalam melakukan pembelian jasa, dan (d) Melakukan lebih banyak bisnis atau pembelian dengan perusahaan beberapa tahun mendatang.

$$
\text { Tjiptono }
$$

mengemukakan enam indikator yang bisa digunakan untuk mengukur loyalitas konsumen yaitu: (a) Pembelian ulang, (b) Kebiasaan mengkonsumsi merek tersebut, (c) Selalu menyukai merek tersebut, (d) Tetap memilih merek tersebut, (e) Yakin bahwa merek tersebut yang terbaik, (f) Merekomendasikan merek tersebut pada orang lain.

Dalam menempatkan pelanggan pada tengah pusaran aktivitas bisnis, diharapkan perusahaan selalu memperhatikan dan mengutamakan pelanggan dalam segala aktivitas maupun program yang dilakukan. Sehingga pelanggan menjadi pihak yang selalu didahulukan, dengan harapan akan merasa puas, nyaman, dan akhirnya menjadi loyal kepada perusahaan.

\section{Hubungan Purna Jual dengan \\ Loyalitas Pelanggan}

Dari dua variabel yang terkait penelitian ini masing-masing memiliki pengertian yang penting bagi perusahaan. Karena pentingnya loyalitas terhadap kelangsungan hidup perusahaan, maka perusahaan harus secara kontinu menjaga dan meningkatkan loyalitas dari para pelanggannya. Oleh karena itu untuk 
membangun loyalitas pelanggan, perusahaan harus memiliki hubungan yang baik dengan pelanggan sehingga perusahaan dapat lebih memahami akan kebutuhan, keinginan dan harapan-harapan para pelanggannya. Maka dari itu harus terbentuk hasil loyalitas pelanggan yang maksimal.

Konsumen melakukan evaluasi dari nilai customization dan reliability atas produk dan jasa yang diterima oleh mereka. Customization diartikansebagai nilai yang dirasakan oleh konsumen atas kesesuian barang dan jasa dengan harapan dan kebutuhan mereka. Sedangkan realibility akan dinilai oleh konsumen dengan melihat dari kinerja, standart, dan efisiensi saat mempergunakan produk atau jasa tersebut. Kedua unsur inilah yang menjadikan suatu produk mampu merubah keputusan pembelian (Weijters et al 2007). Sikap konsumen yang loyal terhadap perusahaan berhubungan dengan faktor kualitas pelayanan yang diberikan oleh perusahaan. Menurut Kotler (2009:45) sebuah perusahaan dapat menarik konsumen dan mengungguli pesaingnya apabila dapat memenuhi kebutuhan konsumen serta dapat memuaskan keinginan mereka. Dengan demikian Tjiptono (2002:59) pada hakikatnya suatu perusahaan yang berwawasan pada konsumen, baik perusahaan manufaktur/jasa akan berusaha mencapai keuntungannya melalui kepuasan konsumen. Kualitas pelayanan mempunyai hubungan yang kuat dengan perusahaan yang menyediakan pelayanan jasa kepadanya. Dengan demikian perusahaan dapat memaksimumkan pengalaman yang kurang menyenangkan. Pada gilirannya kepuasan menciptakan kesetiaan atau loyalitas terhadap perusahaan yang memberikan kualitas pelayanan yang memuaskan.

\section{Kerangka Pemikiran Teoritis}

Berdasarkan pada rumusan masalah dan telaah pustaka yang diuraikan dimuka mengenai variabel bebas Pelayanan Purna Jual. Menurut Kotler (2002) bahwa unsur-unsur dalam layanan purna jual adalah sebagai berikut:

a. Garansi 
b. Penyediaan Aksesoris

c. Pelayanan Pemeliharaan dan Perbaikan

d. Fasilitas dan Perlengkapan

Dalam penelitian ini diambil 3 unsurnya sebagai sub variabel bebas/variabel independen. Dari keempat sub variabel diatas peneliti tidak menggunakan sub variabel pemeliharaan dan perbaikan dikarenakan obyek yang diteliti tidak memenuhi sub variabel tersebut. Kemudian pengaruhnya terhadap variabel dependen loyalitas pelanggan, menurut Tjiptono (2002:85) mengemukakan enam indikator yang bisa digunakan untuk mengukur loyalitas konsumen yaitu: (a) Pembelian ulang, (b) Kebiasaan mengkonsumsi merek tersebut, (c) Selalu menyukai merek tersebut, (d) Tetap memilih merek tersebut, (e) Yakin bahwa merek tersebut yang terbaik dan (f) Merekomendasikan merek tersebut pada orang lain

Kemudian dalam penelitian ini di ambil 3 unsurnya. Namun peneliti tidak menggunakannya sebagai sub variabel. Maka kerangka teoritis yang diajukan dalam penelitian ini digambarkan sebagai berikut. Lihat gambar 2.2 berikut:

Gambar 2.2

Kerangka Pemikiran Teoritis

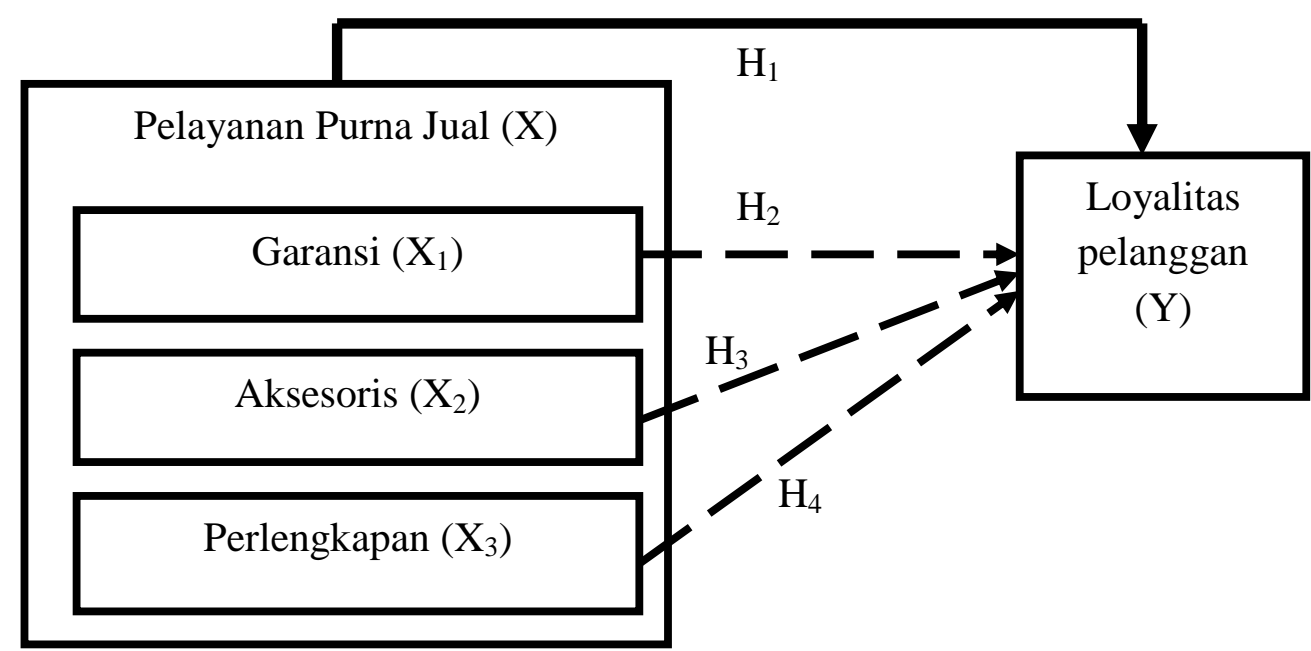




\section{Hipotesis}

Hipotesis merupakan jawaban sementara terhadap rumusan masalah penelitian, dimana rumusan masalah penelitian telah dinyatakan dalam bentuk kalimat pernyataan (Sugiyono, 2005:70).

\section{Simultan:}

$\mathrm{H}_{1}=$ Variabel pelayanan purna jual berpengaruh signifikan terhadap loyalitas konsumen secara simultan

\section{Parsial:}

$\mathrm{H}_{2}=$ Variabel pelayanan garansi berpengaruh signifikan terhadap loyalitas konsumen secara parsial

$\mathrm{H}_{3}=$ Variabel penyediaan aksesoris berpengaruh signifikan terhadap loyalitas konsumen secara parsial

$\mathrm{H}_{4}=$ Variabel penyediaan perlengkapan berpengaruh signifikan terhadap loyalitas konsumen secara parsial

\section{METODEOLOGI PENELITIAN}

Penelitian ini dilakukan di "Outlet J-Teknik Cellular" yang beralamatkan di jalan Sumatra 177 jember, selama kurun waktu bulan Maret hingga Mei 2013. Populasi dalam penelitian ini adalah konsumen loyalis yang membeli produk evercoss di J-Teknik jalan Sumatra 177 Jember sebanyak 250 konsumen dari pembeli sebanyak 1379 konsumen dengan menggunakan jumlah sampel dari Hair sebesar 80 responden.

Variabel dalam penelitian ini meliputi Variabel Independen / variabel bebas $(\mathrm{X})$, yang terdiri dari
(X1) Garansi, (X2) Aksesoris, (X3) Perlengkapan $\left(\mathrm{X}_{3}\right)$. Sedangkan Variabel Y (variabel Dependent) yaitu Loyalitas Pelanggan. Data dikumpulkan dengan beberapa teknik pengumpulan data yaitu observasi, wawancara, dokumentasi.

Setelah data terkumpul selanjutnya akan dianalisis dengan beberapa tahapan yaitu (1) Uji Validitas, (2) Uji Reliabilitas, (3) Uji Asumsi Klasik, (4) Analisis Regresi Linier Berganda, dan (5) Uji Hipotesis. Uji Hipotesis yang digunakan meliputi Uji F dan Uji t. 


\section{HASIL PENELITIAN}

\section{Pengujian Validitas}

Pengujian validitas data digunakan untuk mengukur sah atau valid tidaknya suatu kuesioner. Suatu kuesioner dianggap valid jika pertanyaan pada kuesioner mampu mengungkapkan sesuatu yang diukur oleh kuesioner tersebut. Pengujian validitas menggunakan rumus product moment dari Pearson yang dilakukan dengan menghitung korelasi antar masing-masing skor item pertanyaan dari tiap variabel dengan total skor variabel tersebut. Jika skor item tersebut berkorelasi positif dengan skor total skor item dan lebih tinggi dari korelasi antar item, menunjukkan kevalidan instrumen tersebut. Untuk penelitian ini, nilai df dapat dihitung sebagai berikut df $=$ n-2 atau $80-2=78$, dengan tingkat signifikansi sebesar 0,05 maka didapat $r$ tabel sebesar 0,2199 .

\section{Pengujian Reliabilitas}

Uji reliabilitas digunakan untuk mengukur konsistensi konstruk atau variabel penelitian. Untuk mengukur uji reliabilitas dilakukan dengan menggunakan uji statistik Cronbach Alpha. Suatu konstruk atau variabel dikatakan reliabel jika kriteria pengujiannya sesuai. Untuk penelitian ini, nilai df dapat dihitung sebagai berikut $\mathrm{df}=\mathrm{n}-2$ atau $80-2=$ 78, dengan tingkat signifikansi sebesar 0,05 maka didapat $r$ tabel sebesar 0,2199.

\section{Pengujian Asumsi Klasik}

\section{a. Uji Normalitas}

Uji normalitas bertujuan untuk menguji apakah dalam model regresi variabel dependen dan variabel independen keduanya mempunyai distribusi normal atau tidak. Uji normalitas dihitung menggunakan One-Sample Kolmogorov-Smirnov Test, dan hasil uji dalam penelitian ini menunjukan bahwa KolmogorovSmirnov $Z$ 1,069 dan asymp. Sig. 0,204 lebih besar dari 0,05 maka dapat disimpulkan data yang telah diolah berdistribusi normal dan lulus uji asumsi normalitas. 


\section{b. Uji Multikolinearitas}

Uji multikolinearitas bertujuan untuk menguji apakah dalam model regresi ditemukan adanya korelasi antar variabel bebas (independen). Model regresi yang baik seharusnya tidak terjadi korelasi di antara variabel bebas. Dengan menggunakan kriteria pengujian yang telah disebutkan sebelumnya Variance Inflation Factor (VIF) untuk multikolinearitas adalah tidak melebihi 10,0 dan nilai Tolerance di atas 0,10. Hasil uji multikolinearitas menunjukan bahwa bahwa nilai Tolerance pada semua variabel lebih dari 0,01 dannilai Variance Inflation Factor (VIF) pada semua variabel kurang dari 10,0 maka dapat disimpulkan bahwa tidak ada multikolinearitas antar variabel independen dalam model regresi. Atau dengan kata lain model regresi dalam penelitian ini terbebas dari gejala multikolinearitas.

\section{c. Uji Heteroskedastisitas}

Uji heteroskedastisitas

dilakukan untuk menguji apakah dalam sebuah model regresi terjadi ketidaksamaan varians residual dari satu pengamatan ke pengamatan yang lain tetap, maka disebut heteroskedastisitas. Salah satu cara untuk mendeteksi heteroskedastisitas adalah dengan uji glejser, dengan kriteria pengujian jika semua variabel bernilai $\mathrm{t}$ hitung $<\mathrm{t}$ tabel dan nilai sig. > 0,05 maka tidak terjadi heteroskedastisitas, namun jika thitung > t tabel dan nilai sig. < 0,05 maka terjadi heteroskedastisitas. Dan $\mathrm{t}$ tabel diperoleh dari $\mathrm{df}=\mathrm{n}-\mathrm{k}$ atau 80-4 = 76 maka diperoleh t tabel 1,992. Hasil uji glejser menunjukan bahwa semua variabel memiliki nilai $\mathrm{t}$ hitung lebih kecil dari $\mathrm{t}$ tabel dan nilai sig. lebih besar dari 0,05. Maka dapat disimpulkan bahwa tidak terdapat gangguan heteroskedastisitas pada model regresi.

\section{Analisis Regresi Linier Berganda}

Hasil uji Regresi menunjukan bahwa koefisien determinasi memiliki adjusted $R$ square sebesar 0,318. Hal ini berarti $31,8 \%$ loyalitas konsumen (Y) yang dapat dijelaskan oleh variabel independen yaitu sub variabel garansi, aksesoris dan perlengkapan. Sedangkan sisanya 
$(100 \%-31,8 \%=68,2 \%)$

dijelaskan oleh variabel lain di luar model yang tidak dijelaskan dalam penelitian ini.

Dari hasil uji regresi dapat pula disusun persamaan regresi sebagai berikut: $Y=9,013+0,641 X_{1}+$ $\mathbf{0 , 3 2 3} \mathbf{X}_{\mathbf{2}}+\mathbf{0 , 4 8 9} \mathbf{X}_{\mathbf{3}}$. Persamaan tersebut menunjukan bahwa:

1. Konstanta (a)

Ini berarti jika semua variabel bebas memiliki nilai nol (0) maka nilai variabel terikat (loyalitas konsumen) sebesar 9,013.

2. Garansi $\left(\mathrm{X}_{1}\right)$ terhadap Loyalitas Konsumen (Y)

Nilai koefisien garansi untuk variabel $\mathrm{X}_{1}$ sebesar 0,641. Hal ini mengandung arti bahwa setiap kenaikan garansi satu satuan garansi maka variabel loyalitas konsumen (Y) akan naik sebesar 0,641 dengan asumsi bahwa variabel bebas yang lain dari model regresi adalah tetap.

3. Aksesoris $\left(\mathrm{X}_{2}\right)$ terhadap Loyalitas Konsumen (Y)

Nilai koefisien aksesoris untuk variabel $\mathrm{X}_{2}$ sebesar 0,323 . Hal ini mengandung arti bahwa setiap kenaikan aksesoris satu satuan maka variabel loyalitas konsumen (Y) akan naik sebesar 0,323 dengan asumsi bahwa variabel bebas yang lain dari model regresi adalah tetap.

4. Perlengkapan $\left(\mathrm{X}_{3}\right)$ terhadap Loyalitas Konsumen (Y)

Nilai koefisien perlengkapan untuk variabel $\mathrm{X}_{3}$ sebesar 0,489 . Hal ini mengandung arti bahwa setiap kenaikan perlengkapan satu satuan maka variabel loyalitas konsumen (Y) akan naik sebesar 0,489 dengan asumsi bahwa variabel bebas yang lain dari model regresi adalah tetap.

\section{Pengujian Hipotesis (Uji F dan Uji t)}

\section{a. Hasil Uji F}

Uji $F$ digunakan untuk mengetahui apakah variabel independen secara simultan berpengaruh signifikan terhadap variabel dependen. Derajat kepercayaan yang digunakan adalah 0,05. Apabila nilai $\mathrm{F}$ hasil perhitungan lebih besar daripada nilai $\mathrm{F}$ menurut tabel maka hipotesis alternatif, yang menyatakan bahwa semua variabel independen secara simultan berpengaruh signifikan terhadap variabel dependen. $\mathrm{F}$ tabel diperoleh dari df1 = k-1 atau 4-1 = 3 
dan df $2=80-4=76$ maka diperoleh F tabel 2,72.

Berdasarkan uji ANOVA atau F test yang dapat dilihat pada Tabel 4.11, maka dapat diperoleh $\mathrm{F}$ hitung sebesar 13,275 lebih besar dari $\mathrm{F}$ tabel 2,72. Jadi $\mathrm{F}$ hitung > F tabel maka $\mathrm{H}_{0}$ ditolak dan $\mathrm{H}_{\mathrm{a}}$ diterima dan dapat disimpulkan bahwa variabel independen yang meliputi garansi $\left(\mathrm{X}_{1}\right), \quad$ aksesoriss $\left(\mathrm{X}_{2}\right), \quad$ dan perlengkapan $\left(\mathrm{X}_{3}\right)$ secara simultan atau bersama-sama berpengaruh signifikan terhadap variabel loyalitas konsumen (Y).

\section{b. Uji t}

Uji t yaitu suatu uji untuk mengetahui signifikansi pengaruh sub variabel bebas (garansi, aksesoris dan perlengkapan) secara parsial atau individual menerangkan variabel terikat (loyalitas konsumen). Uji $\mathrm{t}$ digunakan untuk mengetahui apakah sub variabel independen secara parsial berpengaruh nyata atau tidak terhadap variabel dependen. Derajat signifikansi yang digunakan adalah 0,05 . Apabila nilai signifikan lebih kecil dari derajat kepercayaan maka kita menerima hipotesis alternatif, yang menyatakan bahwa suatu sub variabel independen secara parsial mempengaruhi variabel dependen.

Hasil uji t pada penelitian ini menunjukan bahwa :

a. Garansi $\left(\mathrm{X}_{1}\right)$ terhadap Loyalitas Konsumen (Y)

Terlihat pada tabel regresi hasil uji t sub variabel garansi $\left(\mathrm{X}_{1}\right)$ mempunyai t hitung yakni 3,049 dengan $\mathrm{t}$ tabel $=1,992$. Jadi $\mathrm{t}$ hitung $>\mathrm{t}$ tabel maka $\mathrm{H}_{0}$ ditolak dan $\mathrm{H}_{\mathrm{a}}$ diterima maka dapat disimpulkan bahwa variabel pelayanan garansi $\left(\mathrm{X}_{1}\right)$ berpengaruh signifikan terhadap loyalitas konsumen (Y).

b. Aksesoris $\left(\mathrm{X}_{2}\right)$ terhadap Loyalitas Konsumen (Y)

Terlihat pada tabel garansi sub variabel aksesoris $\left(\mathrm{X}_{2}\right)$ mempunyai t hitung yakni 1,923 dengan $\mathrm{t}$ tabel $=1,992$. Jadi $\mathrm{t}$ hitung $<\mathrm{t}$ tabel maka $\mathrm{H}_{0}$ diterima dan $\mathrm{H}_{\mathrm{a}}$ ditolak maka dapat disimpulkan bahwa variabel aksesoris $\left(\mathrm{X}_{2}\right)$ tidak berpengaruh signifikan terhadap loyalitas konsumen (Y).

c. Perlengkapan $\left(\mathrm{X}_{3}\right)$ terhadap Loyalitas Konsumen (Y)

Terlihat pada tabel regresi sub variabel perlengkapan 
$\left(\mathrm{X}_{3}\right)$ mempunyai t hitung yakni 2,317 dengan $\mathrm{t}$ tabel $=1,992$. Jadi $\mathrm{t}$ hitung $>\mathrm{t}$ tabel maka $\mathrm{H}_{0}$ ditolak dan $\mathrm{H}_{\mathrm{a}}$ diterima dan dapat disimpulkan bahwa variabel perlengkapan $\left(\mathrm{X}_{3}\right)$ berpengaruh signifikan terhadap loyalitas konsumen (Y).

\section{PEMBAHASAN}

$\mathrm{H}_{1}=$ Variabel layanan purna jual berpengaruh signifikan terhadap loyalitas konsumen secara simultan.

Dari hasil analisis layanan purna jual dianggap benar-benar penting dan menjadi prioritas utama konsumen dalam membeli produk, sebab dengan adanya layanan purna jual konsumen dapat yakin dan merasa tenang terhadap produk apabila terjadi kerusakan dalam jangka waktu kedepan. Maka dapatdinyatakan bahwa variabel independen yang meliputi garansi $\left(\mathrm{X}_{1}\right), \quad$ aksesoriss $\left(\mathrm{X}_{2}\right), \quad$ dan perlengkapan $\left(\mathrm{X}_{3}\right)$ secara simultan atau bersama-sama berpengaruh signifikan terhadap variabel loyalitas konsumen (Y) di outlet J-Teknik Cellular.

$\mathrm{H}_{2}$ : garansi berpengaruh signifikan terhadap loyalitas konsumen.
Hal tersebut dapat dilihat dari hasil analisis dan sesuai pula dengan hasil wawancara peneliti dengan para responden bahwa:

1. Konsumen dalam membeli produk (evercoss) selalu bertanya tentang konsistensi toko dalam memberikan serta melaksanakan perjanjian garansi sesuai yang diakadkan.

2. Komplain tentang kerusakan selalu ditanggapi dan dilayani dengan baik oleh toko dan karyawan.

3. Penyelesaian kerusakan selalu diupayakan dalam waktu yang tidak terlalu lama, sehingga konsumen merasa puas.

4. Garansi bagi konsumen dirasa sebagai bagian yang tak terpisahkan dari layanan purna jual atau bahkan sebagai layanan yang melekat.

Dengan demikian dapat disimpulkan bahwa semakin tinggi dan semakin 
baik layanan garansi yang diberikan oleh J-Teknik Cellular kepada konsumen, maka akan semakin tinggi pula loyalitas konsumennya terhadap ponsel merek evercoss.

$\mathrm{H}_{3} \quad$ : aksesoris tidak berpengaruh signifikan terhadap loyalitas konsumen.

Hal tersebut dapat dilihat dari hasil analisis dan sesuai pula dengan hasil wawancara peneliti dengan para responden bahwa:

1. Aksesoris kurang begitu diminati oleh beberapa konsumen sebab saat konsumen melakukan pembelian awal, aksesoris sudah terintegrasi di dalam paket pembelian.

2. Konsumen akan membeli aksesoris hanya apabila aksesoris bawaan mengalami kerusakan atau hilang dan biasanya dalam jangka waktu yang relatif lama.

3. Konsumen juga merasa dapat membeli komponen aksesoris ditempat lain atau bahkan tanpa ragu menggunakan aksesoris yang tidak asli/tidak resmi, dari hal ini mengakibatkan jumlah pembelian rendah.

4. Beberapa konsumen merasa tidak terlalu menggunakan beberapa jenis aksesoris berlebihan dan menganggap tidak terlalu penting.

Dengan demikian dapat disimpulkan bahwa aksesoris tidak berpengaruh signifikan terhadap loyalitas konsumen. Konsumen menganggap penyediaan aksesoris kurang dibutuhkan oleh sebagian konsumen.

$\mathrm{H}_{4} \quad$ : perlengkapan berpengaruh signifikan terhadap loyalitas konsumen.

Hal tersebut dapat dilihat dari hasil analisis dan sesuai pula dengan hasil wawancara peneliti dengan para responden bahwa:

1. Menurut konsumen perlengkapan jenis aplikasi sangat dibutuhkan sebab sangat mendukung dalam penggunaan produk, pemberian bonus aplikasi memudahkan konsumen untuk mendapatkan beberapa aplikasi secara gratis dan tidak lagi mengeluarkan biaya tambahan. 
2. Konsumen tertarik dalam memberikan nilai tambah bagi menggunakan perlengkapan konsumen.

jenis screenguard karena bagi pengguna produk ponsel layar lebar menggunakan pelindung layar dapat melindungi ponsel dari radiasi cahaya dan terjaga dari goresan yang dapat mengganggu pandangan, dengan adanya screenguard

3. Perlengkapan jenis powerbank mendapat tanggapan baik oleh konsumen pasalnya perlengkapan jenis ini membantu konsumen dalam kesulitan pengisi daya saat bepergian jauh, saat pemadaman listrik dan hal-hal mendesak lainnya.

\section{KESIMPULAN}

1. Berdasarkan hasil penelitian pada BAB IV maka diperoleh persamaan regresi linier berganda sebagai berikut:

$Y=9,013+0,641 X_{1}+0,323 X_{2}+$

\section{$\mathbf{0 , 4 8 9} \mathrm{X}_{3}$}

Berdasarkan analisis regresi linier berganda, maka dapat dilihat bahwa yang paling berpengaruh terhadap variabel loyalitas konsumen adalah sub variabel garansi dengan nilai koefisien regresi sebesar 0,641 , hal ini mengandung arti bahwa setiap kenaikan garansi satu satuan maka variabel loyalitas konsumen. Kemudian sub variabel aksesoris dengan nilai koefisien regresi sebesar 0,323. Dan sub variabel perlengkapan berpengaruh signifikan dengan nilai koefesien regresi sebesar 0,489 .

2. Pada pengujian hipotesis dengan menggunakan uji $F$ (secara bersama-sama atau simultan) dapat dijelaskan bahwa ketiga sub variabel yaitu garansi $\left(\mathrm{X}_{1}\right)$, aksesoris $\left(\mathrm{X}_{2}\right)$, perlengkapan $\left(\mathrm{X}_{3}\right)$, terhadap variabel terikat loyalitas konsumen (Y) secara bersama-sama berpengaruh terhadap loyalitas konsumen. Hal ini ditunjukkan dari nilai $\mathrm{F}$ hitung sebesar 13,275.

3. Nilai koefisien determinasi $\left(\mathrm{R}^{2}\right)$ yang dihasilkan adalah 0,318 . Hal ini berarti sebesar 31,8 persen perubahan variabel loyalitas 
konsumen dapat dijelaskan olehperubahan variabel garansi, aksesoris dan perlengkapan secara bersama-sama, sedangkan sisanya sebesar 68,2 persen dijelaskan oleh variabel lain yang tidak terdapat dalam penelitian ini.

4. Pada pengujian hipotesis sub variabel garansi berpengaruh signifikan dan memiliki nilai t hitung 3,049 lebih besar dari t tabel dan nilai signifikan 0,003 lebih kecil dari 0,05 . Hal ini dapat dinyatakan sub variabel garansi berpengaruh signifikan terhadap loyalitas konsumen.

5. Pada pengujian hipotesis sub variabel aksesoris tidak berpengaruh signifikan dan memiliki nilai t hitung
1,923 lebih kecil dari t tabel dan nilai signifikan 0,058 lebih besar dari 0,05 . Hal ini dapat dinyatakan sub variabel aksesoris tidak berpengaruh signifikan terhadap loyalitas konsumen.

6. Pada pengujian hipotesis sub variabel perlengkapan berpengaruh signifikan dan memiliki nilai t hitung 2,317 lebih besar dari t tabel dan nilai signifikan 0,023 lebih kecil dari 0,05 . Hal ini dapat dinyatakan sub variabel perlengkapan berpengaruh signifikan terhadap loyalitas konsumen.

\section{DAFTAR PUSTAKA}

Arikunto, Suharsini. 2002. Prosedur penelitian suatu pendekatan praktek. PT. Rineka Cipta. Jakarta

Badan Pusat Statistik, 2013. Jember Dalam Angka. BPS Kabupaten Jember

Barata, Atep Adya. 2003. DasarDasar Pelayanan Prima. PT Gramedia Pustaka.Jakarta

Blischke, Wallace R. And Murthy, D.N. Prabharkar.1994.
Warranty Cost Analysis. Marcel Dekker Inc : New York Chan, Syafruddin. 2002. Relationship marketing : inovasi pemasaran Yang membuat pelanggan bertekuk lutut. PT. Gramedia Pustaka Utama. Jakarta

Engel, Blackwell dan Miniard. 1994. Perilaku Konsumen. Binarupa Aksara. Jakarta

Ghozali, Imam. 2001. "Analisis Multivariate dengan Program 
SPSS". Badan Penerbit Universitas Diponegoro. Semarang

-----------------. 2005. “Analisis Multivariate dengan Program SPSS". Badan Penerbit Universitas Diponegoro. Semarang

Griffin, Jill. 1995. Costumer Loyalty : menumbuhkan dan mempertahankan kesetiaan pelanggan. Airlangga. Jakarta

-------------. 2003. Costumer Loyalty : menumbuhkan dan mempertahankan pelanggan. Airlangga. Jakarta

Hair. 1995. Multivariate Data Analysis. Englewood Cliffs. New Jerseys

Hasan, Ali. 2008. Marketing. Media Utama. Yogyakarta

Hindle, Tim, Thomas M. 1994. Manajemen alih bahasa Ramiano $Q$ Roosmin. Dian rakyat. Jakarta

Hurriyati, Ratih. 2008. Bauran Pemasaran dan Loyalitas konsumen. Alfabeta. Bandung

Kotler, Philip. 1997. Manajemen Pemasaran (Analisis, Perencanaan, Implementasi dan Kontrol). Prenhalilindo. Jakarta

-------------------. 2001. Manajemen Pemasaran di Indonesia : Analisis, Perencanaan, Implementasi dan Pengendalian. Salemba Empat. Jakarta.

Pemasaran, Jilid I, Edisi Milenium. PT.

Prenhallindo. Jakarta

Mas'ud, Fuad. 2004. Survai Diagnosis Organisasional Konsep \& Aplikasi. Badan
Penerbit Universitas

Diponegoro. Semarang Normasari, Selvy, Srikandi Kumadji, Andriani Kusumawati. Desember 2013. Pengaruh Kualitas Pelayanan terhadap Kepuasan Pelanggan, Citra Perusahaan Dan Loyalitas Pelanggan. Jurnal Administrasi Bisnis, No. 2Vol. 6 hal. 1-9

Paliati, Alida. 2004. Pengaruh Tingkat Kepuasan terhadap Loyalitas Nasabah Tabungan Perbankan di Wilayah Etnis Bugis. Jurnal analisis, No. 2 Vol. 1

Sadjojo, Nidjo. 2011. Metode Analisis jalur dan Aplikasinya. Pustaka Sinar Harapan. Jakarta Stanton, W.J 1994. Fundamental of Marketing. Thenthed. Mc, Graw Hill Inc. Singapore

Subagyo, Pangestu. 2004. Statistik Terapan. BPFE. Yogyakarta

Sugiyono. 2005. Memahami Penelitian Kualitatif. Alfabeta. Bandung

-----------. 2010. Metode Penelitian Pendidikan. Alfabeta. Bandung -----------. 2011. Statistik untuk Penelitian. Alfabeta. Bandung .2012. Metode penelitian kuantitatif Kualitatif dan $R \& D$. Alfabeta. Bandung

Suprapto. 2006. Pengukuran Tingkat Kepuasan Pelanggan. Cetakan ketiga. Rineka. Jakarta

Sussanto, Herry, Wido Damayanti. April 2008. Pengaruh Kualitas Pelayanan dan Produk Terhadap Loyalitas Konsumen. Jurnal ekonomi bisnis no. 1 vol. 13, hal. 59-67

Swastha, Basu. 1994. Manajemen Pemasaran Moderen. Liberty. Yogyakarta 
2001. Manajemen

Pemasaran Modern. BPFE. Yogyakarta

Tjiptono, Fandy.2000. Strtategi Pemasaran. Andi. Yogyakarta 2002. Manajemen

Jasa. Edisi I, Cetakan Ketiga. Andi Offset. Yogyakarta

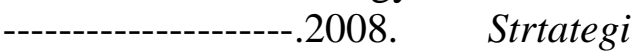

Bisinis Pemasaran. Andi.

Yogyakarta

Undang-undang nomor 8 tahun 1999 tentang perlindungan konsumen

Wijters, Bert, Devarajan Rangarajan,

Tomas Falk, and Niels Schillewaert. August 2007.

Determinants and Outcomes of Consumers Use of Self-Service
Technology in a Retail Setting. Jurnal of research, no. 1 Vol. 10

Wijaya , Tony, Maret 2008. Pengaruh Kepuasan pada Penanganan Keluhan dan Citra Perusahaan Terhadap Loyalitas Konsumen Natasha Skin Care, Jurnal Ekonomi Bisnis No. 1 Vol. XIV, hal. 5569

Winardi. 1991. Marketing dan Perilaku Konsumen. Mandar Maju. Bandung www.lintascinta.com diakses pada tanggal 29 Juni 2014, 04.07 wib www.SWA.co.id diakses pada tanggal 15 April 2014, 21.30 wib 